\title{
PENGARUH PENGALAMAN PENDIDIKAN KEWIRAUSAHAAN DAN KETERAMPILAN KEJURUAN TERHADAP MOTIVASI BERWIRAUSAHA SISWA
}

\author{
Anita Volintia Dewi \\ Program Studi Pendidikan Teknologi dan Kejuruan PPs UNY \\ anitavode@ymail.com \\ Endang Mulyatiningsih \\ Fakultas Teknik Universitas Negeri Yogyakarta \\ ememulya63@gmail.com
}

Abstrak

Penelitian ini bertujuan untuk mengkaji pengaruh pengalaman pendidikan kewirausahaan di sekolah, keluarga dan masyarakat serta keterampilan kejuruan terhadap motivasi berwirausaha siswa. Penelitian ini merupakan penelitian ex-post facto. Populasi penelitian adalah 110 siswa SMK kelas 3 yang terdiri dari 19 siswa SMK N 1 Gantiwarno, 71 siswa SMK N 3 Klaten, enam siswa SMK Tunas Cawas dan 14 siswa SMK Bina Patria Bangsa. Pengalaman pendidikan kewirausahaan di sekolah, keluarga, masyarakat dan keterampilan kejuruan secara bersama-sama memiliki hubungan terhadap motivasi berwirausaha. Nilai hubungan tersebut adalah 0,460 (kategori sedang). Sedangkan kontribusi secara bersama-sama adalah 21,2\%. Dari keempat faktor tersebut, pengaruh keterampilan kejuruan lebih besar kontribusinya terhadap motivasi berwirausaha siswa.

Kata kunci: pengalaman pendidikan kewirausahaan di sekolah, keluarga, masyarakat, keterampilan kejuruan, dan motivasi berwirausaha

\section{THE EFFECT OF ENTREPRENEURSHIP EDUCATION EXPERIENCES AND VOCATIONAL SKILLS ON THE ENTREPRENEURSHIP MOTIVATION OF FASHION MAJORING STUDENTS}

\begin{abstract}
This study aimed to examine the effect of entrepreneurial education experience in schools, families, communities and vocational skills on students' entrepreneurship motivation. This study is an expost facto research. The population was 110 year three vocational students comprising 19 students of SMK N 1 Gantiwarno, 71 students of SMK N 3 Klaten, six students of SMK Tunas Cawas and 14 students of SMK Bina Patria Bangsa. The entrepreneurship education experience in schools, families, communities and vocational skills together have correlation with entrepreneurship motivation. The correlation coefficient is 0.460 (medium category). While a contribution together is $21,2 \%$. Of all factors, the effect of vocational skills has more contribution to the students' entrepreneurship motivation.
\end{abstract}




\section{PENDAHULUAN}

Berdasarkan orientasi pendidikan kejuruan yang menyiapkan peserta didiknya untuk masuk dunia kerja, maka pendidikan kejuruan mempunyai peran strategis dalam meningkatkan kualitas sumber daya manusia (SDM). Sumber daya manusia yang berkualitas akan berperan pada peningkatan perekonomian nasional. Secara sederhana, pendidikan kejuruan mempunyai peran strategis dalam upaya meningkatkan perekonomian nasional. Menurut Thompson (1973:93), vocational education is economic education as it is geared to the needs of the job market and thus contributes to national economic strength. Pendapat tersebut menunjukkan bahwa pendidikan kejuruan merupakan pendidikan ekonomi yang menyuplai bursa kerja dan mendorong kekuatan ekonomi nasional. Dalam proses pembelajaran, Sekolah Menengah Kejuruan (SMK) membekali siswa dengan pengetahuan dan keterampilan yang dibutuhkan di dunia kerja. Selain itu, siswa SMK juga dibekali pendidikan kewirausahaan, malalui mata pelajaran Kewirausahaan. Hasil studi cepat Pendidikan Kewirausahaan pada Pendidikan Dasar dan Menengah Kementerian Pendidikan Nasional (Kemendiknas), menunjukkan bahwa orientasi lulusan SD, SMP, sampai SMA dan SMK masih untuk mencari kerja bukan sebagai wirausaha (sumber: http://www.republika.co.id/berita/pendidikan/ berita/10/05/28/117497-pendidikanwirausaha-tak-bisa-instan).

Motivasi berwirausaha lulusan SMK yang rendah menjadi sebuah permasalahan, maka pelajaran pendidikan kewirausahaan di SMK yang selama ini diberikan masih diragukan pengaruhnya. Kemudian timbul pertanyaan, sebenarnya apa saja yang mempengaruhi motivasi berwirausaha siswa SMK? Pendidikan kewirausahaan yang tercantum dalam kurikulum SMK, secara langsung maupun tidak langsung diharapkan memberikan pengaruh terhadap motivasi berwirausaha karena memberikan dasar pengetahuan kewirausahaan. Menurut Potter (2008: 182), Key role of entrepreneurial education is to create momentum for change; development starts in small steps, as others follow and momentum grows. Pendapat tersebut dapat dimaknai bahwa pendidikan kewirausahaan dimanfaatkan sebagai momentum awal menciptakan lulusan yang berjiwa wirausaha melalui pembentukan pola pikir (mindset) dan jiwa (spirit) menjadi pengusaha.

Pengalaman pendidikan peserta didik dapat diperoleh dari berbagai lingkungan, bukan hanya di lingkungan sekolah melainkan melalui masyarakat dan keluarga. Lingkungan masyarakat dan budaya dapat memberikan pengalaman kewirausahaan ketika lingkungan tersebut merupakan sentra wirausaha. Sama halnya dengan keluarga, orang tua yang berwirausaha atau tidak berwirausaha akan memberikan pengalaman kepada anaknya. Motivasi untuk berwirausaha tidak cukup hanya dibekali dengan pengetahuan atau pendidikan kewirausahaan. Harus ada bekal keterampilan mengenai bidang apa yang akan dijadikan usaha atau menjadi fokus wirausaha. SMK merupakan pendidikan yang membekali pengetahuan dan keterampilan kejuruan tertentu kepada peserta didiknya. Pengetahuan dan keterampilan tersebut, bukan hanya dapat dimanfaatkan untuk mencari pekerjaan di industri/perusahaan, tetapi juga diharapkan dapat digunakan sebagai bekal untuk mandiri dengan membuka usaha sendiri. Berdasarkan hal tersebut di atas maka harus dilakukan penelitian tentang pengaruh pengalaman pendidikan kewirausahaan dan keterampilan kejuruan terhadap motivasi berwirausaha siswa SMK Tata Busana di Kabupaten Klaten.

Permasalahan penelitian adalah bagaimana pengaruh pengalaman pendidikan kewirausahaan di sekolah terhadap motivasi berwirausaha siswa SMK Tata Busana di Klaten? Harapan ke depan jika pendidikan kewirausahaan mampu mengubah sikap mental dari pencari kerja ke menciptakan pekerjaan, maka akan memberi pengaruh penciptaan lapangan kerja baru bagi beberapa tenaga kerja sehingga akan mampu memberikan andil dalam perkembangan ekonomi. Hasil penelitian ini diharapkan berpengaruh dalam penataan ekonomi daerah, maupun memberikan pengaruh dalam pengambilan kebijakan tentang orientasi pengembangan SMK di Klaten.

\section{METODE PENELITIAN}

\section{Jenis Penelitian}

Jenis penelitian ini adalah penelitian $e x$ post fact. Peneliti tidak memanipulasi keadaan karena faktanya telah terjadi. Data dikumpul- 
kan setelah semua kejadian yang dipersoalkan sudah terjadi untuk menjelaskan akibat pada saat ini.

\section{Tempat dan Waktu Penelitian}

Penelitian ini dilaksanakan di SMK Program Studi Keahlian Tata Busana di wilayah Kabupaten Klaten, yaitu di SMK N 1 Gantiwarno, SMK N 3 Klaten, SMK Tunas Cawas, dan SMK Bina Patria Bangsa. Waktu penelitian pada bulan Mei - Juli 2012.

\section{Populasi dan Sampel Penelitian}

Populasi dalam penelitian ini berjumlah 153 orang siswa yang merupakan seluruh siswa kelas XII SMK Program Studi Keahlian Tata Busana di Kabupaten Klaten. Untuk mendapatkan jumlah sampel yang representative terhadap populasi, maka digunakan rumus penentuan jumlah sampel yang dibuat oleh Isaac dan Michael dalam Sukardi (2010: 55), dengan rumus:

$$
s=\frac{\mathrm{x}^{2} \cdot \mathrm{N} \cdot \mathrm{P}(1-\mathrm{P})}{\mathrm{d}^{2}(\mathrm{~N}-1)+\mathrm{x}^{2} \cdot \mathrm{P}(1-\mathrm{P})}
$$

Keterangan:

$$
\begin{array}{ll}
\mathrm{S} & =\text { jumlah sampel } \\
\mathrm{N} & =\text { jumlah populasi } \\
\mathrm{P} & =\text { proporsi populasi }(\mathrm{P}=0,5) \\
\mathrm{D} & =\text { derajat ketepatan }(\mathrm{d}=0,05) \\
\mathrm{X} 2 & =\text { Nilai chisquare, dengan } \mathrm{dk}=1
\end{array}
$$

Taraf signifikansi yang digunakan pada penentuan jumlah sampel tersebut adalah 5\%, sehingga akan diperoleh nilai $X^{2}=3,841$. Dengan demikian, jumlah sampel yang diperoleh dari populasi adalah 109,64 atau dibulatkan menjadi 110 responden $(71,89 \%$ dari populasi). Teknik pengambilan sampel menggunakan metode acak (Random Sampling). Hal itu dilakukan agar setiap anggota populasi memiliki kesempatan/ peluang yang sama untuk menjadi anggota sampel.

\section{Variabel Penelitian}

Variabel dalam penelitian ini adalah pengalaman pendidikan kewirausahaan di sekolah (X1), keluarga (X2) dan masyarakat (X3), serta keterampilan kejuruan (X4) sebagai variabel bebas; dan variabel dependen adalah motivasi berwirausaha (Y).

\section{Teknik dan Instrumen Pengumpulan Data}

Untuk memperoleh data yang relevan untuk penelitian ini, maka akan digunakan teknik angket (questionnaire), observasi dan dokumentasi. Dokumentasi dipergunakan untuk memperoleh data mengenai jumlah siswa dan nilai akhir semester mata diklat produktif siswa SMK Program Studi Keahlian Tata Busana. Observasi dipergunakan untuk memperoleh data mengenai hasil praktek siswa dan bagaimana performance siswa. Angket disusun sedemikian rupa sehingga mampu mengungkap variabel yang diteliti yaitu motivasi berwirausaha dan pengalaman pendidikan kewirausahaan. Angket yang digunakan adalah angket tertutup, karena responden tinggal memilih jawaban yang sudah tersedia.

\section{Validitas dan Reliabilitas Instrumen}

Instrumen penelitian diuji menggunakan validitas isi (Content validity) dan validitas konstruk (Construct validity). Validasi isi dilakukan pada isntrumen lembar observasi keterampilan kejuruan. Dilakukan validasi isi instrumen bertujuan untuk menyesuaikan isi instrumen dengan silabus yang digunakan untuk pembelajaran keterampilan tata busana SMK Tata Busana di Klaten. Pengujian instrumen secara empiris dilakukan pada 30 orang. Jumlah tersebut sesuai dengan pendapat Sugiyono (2010: 125). Sampel diambil dari siswa kelas 3 program studi keahlian Tata Busana SMK Karya Rini Yogyakarta. Hasil uji coba instrumen kemudian dianalisis. Setelah diperoleh data melalui uji coba instrumen, selanjutnya untuk mengetahui item-item dalam instrumen tersebut valid maka digunakan teknik korelasi Product Moment dari Carl Pearson menggunakan SPSS 16 untuk instrumen angket. Pengambilan keputusan berdasarkan nilai probabilitas sig. (2-tailed) dan penjelasan tanda bintang $(* / * *)$ pada nilai korelasi pearson (Hartono, 2010:58). Apabila sig. (2-tailed) $<0,05$ dan terdapat tanda bintang $(* / * *)$ pada nilai korelasi berarti item tersebut valid. Item yang tidak valid tidak digunakan lagi dalam instrumen untuk mengumpulkan data penelitian, karena tidak mengurangi indikator inti instrumen penelitian.

Uji reliabilitas menggunakan reliabilitas internal, dengan tujuan untuk menganalisis konsistensi butit-butir instrument, yaitu menggunakan teknik alpha cronbach's dengan ban- 
tuan SPSS 16. Kemudian hasil dari $\mathrm{n}$ ter-sebut dikonsultasikan dengan harga kategori $r$ untuk mengetahui apakah data tersebut reliabel (andal). Tiap item angket tersebut, dikonsultasikan nilai $\mathrm{r}_{\text {tabel }}$ pada $\mathrm{N}=30$ pada $\alpha=5 \%$ adalah 0,361 . Kriteria item angket yang reliabel yaitu $r_{\text {hitung }}$ lebih dari $r_{\text {tabel. }}$. Dari hasil perhitungan, diketahui bahwa instrumen penelitian reliabel.

\section{Teknik Analisis Data}

Penelitian ini menggunakan analisis deskriptif kuantitatif dan inferensial (analisis regresi). Data yang diperoleh dari penelitian kemudian dianalisis dengan statistik deskriptif masing-masing variabel dengan menggunakan bantuan program SPSS 16, maka akan diperoleh harga rerata $(\mathrm{M})$, median $(\mathrm{Me})$, modus (Mo), dan simpangan baku (SD). pengujian asumsi dalam penelitian ini meliputi pengujian normalitas, linieritas dan multikolinieritas.

\section{Uji Hipotesis}

Untuk menganalisa data yang diperoleh, menggunakan teknik regresi ganda. Sebagai kriteria penerimaan dan penolakan digunakan tingkat signifikansi $5 \%$. Untuk mengetahui korelasi masing-masing variabel bebas dengan variabel terikat, serta untuk mengetahui besarnya pengaruh masing-masing variabel bebas terhadap variabel terikat digunakan analisis regresi sederhana.

Pedoman interpretasi koefisien korelasi (Sugiyono, 2007: 257) adalah sebagai berikut:

Tabel 1. Pedoman interpretasi koefisien korelasi

\begin{tabular}{cc}
\hline Interval Koefisien & Tingkat Hubungan \\
\hline $0,00-0,199$ & Sangat rendah \\
$0,20-0,399$ & Rendah \\
$0,40-0,599$ & Sedang \\
$0,60-0,799$ & Kuat \\
$0,80-1,000$ & Sangat Kuat \\
\hline
\end{tabular}

Dengan melakukan uji signifikansi dua pihak, akan diketahui daerah penolakan atau penerimaan Ho dan Ha, berdasarkan tabel di atas.

\section{HASIL PENELITIAN DAN PEMBAHASAN}

\section{Pengalaman Pendidikan Kewirausahaan di Sekolah}

Skor minimal 35 dan skor maksimal 48, dari skor terendah yang mungkin dicapai yaitu 13 dan tertinggi 52. Statistik deskriptif untuk variabel pengalaman pendidikan kewirausahaan di sekolah menunjukkan perolehan mean (M) sebesar 41,64, median (Me) sebesar 42, Mode (Mo) sebesar 42, dan simpangan baku (SB) sebesar 2,81. Skor variabel pengalaman pendidikan kewirausahaan di sekolah dikelompokkan menjadi empat kategori, yaitu: sangat tinggi, tinggi, rendah, dan sangat rendah. Kategori sangat tinggi mencakup skor rerata tambahan dengan $1 \mathrm{SB}$ sampai dengan skor maksimal yaitu 44,76 sampai dengan 48 . Skor kategori sangat tinggi dicapai oleh 16 orang responden atau $14,54 \%$ dari seluruh responden.

Tabel 2. Distribusi Pengalaman Pendidikan Kewirausahaan di sekolah

\begin{tabular}{|c|c|c|c|c|}
\hline No & Kategori & Interval & Frekuensi & $\%$ \\
\hline 1 & $\begin{array}{l}\text { Sangat } \\
\text { Tinggi }\end{array}$ & $X \geq 44,45$ & 16 & 14,54 \\
\hline 2 & Tinggi & $\begin{array}{c}44,45>X \geq \\
41,64\end{array}$ & 43 & 39,09 \\
\hline 3 & Rendah & $\begin{array}{c}41,64>X \geq \\
38,83\end{array}$ & 37 & 33,64 \\
\hline 4 & $\begin{array}{l}\text { Sangat } \\
\text { Rendah }\end{array}$ & $X<38,83$ & 14 & 12,73 \\
\hline \multicolumn{3}{|c|}{ JUMLAH } & 110 & 100 \\
\hline
\end{tabular}

Kategori tinggi mencakup skor rerata sampai dengan skor rerata ditambah $1 \mathrm{SB}$ yaitu 41,64 sampai dengan 44,45. Skor kategori tinggi dicapai 43 orang responden atau $39,09 \%$ dari seluruh responden. Kategori rendah mencakup skor rerata dikurangi $1 \mathrm{SB}$ sampai dengan rerata yaitu yang besarnya 38,83 sampai dengan 41,64. Skor kategori rendah dicapai oleh 37 orang responden atau $33,64 \%$ dari seluruh responden. Kategori sangat rendah mencakup skor minimal sampai dengan rerata dikurangi $1 \mathrm{SB}$ yang besarnya 35 sampai dengan 38,83. Skor kategori sangat rendah dicapai oleh 14 orang responden atau $12,73 \%$ dari seluruh responden. 


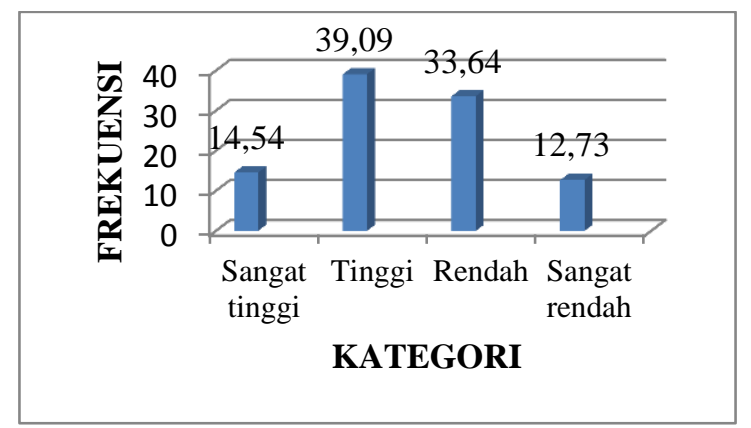

Gambar 1. Distribusi Pengalaman Pendidikan Kewirausahaan di Sekolah Siswa

SMK Tata Busana

\section{Pengalaman Pendidikan Kewirausahaan di Keluarga}

Hasil analisis deskriptif untuk variabel $\mathrm{X} 2$, pengalaman pendidikan kewirausahaan di lingkungan keluarga melalui statistik deskriptif yang secara lengkap terdapat pada lampiran 5 menunjukkan skor minimal 25 dan skor maksimal 40, dari skor terendah yang mungkin dicapai yaitu 11 dan tertinggi 44. Statistik deskriptif untuk variabel pengalaman pendidikan kewirausahaan di lingkungan keluarga menunjukkan perolehan mean (M) sebesar 32,33, median (Me) sebesar 32,50, Mode (Mo) sebesar 34, dan simpangan baku (SB) sebesar 3,10.

Kategori sangat tinggi mencakup skor rerata tambahan dengan 1SB sampai dengan skor maksimal yaitu 35,43 sampai dengan 40 . Skor kategori sangat tinggi dicapai oleh 15 orang responden atau $13,64 \%$ dari seluruh responden.

Tabel 3. Distribusi Pengalaman Pendidikan Kewirausahaan di Keluarga

\begin{tabular}{ccccc}
\hline No & Kategori & Interval & Frekuensi & $\%$ \\
\hline 1 & Sangat & $\mathrm{X} \geq 35,43$ & 15 & 13,64 \\
& Tinggi & & & \\
2 & Tinggi & $35,43>\mathrm{X} \geq$ & 40 & 36,36 \\
& & 32,33 & & \\
& & & \\
3 & Rendah & $32,33>\mathrm{X} \geq$ & 34 & 30,91 \\
& & 29,23 \\
4 & Sangat & $\mathrm{X}<29,23$ & 21 & 19,09 \\
& Rendah & & \\
\hline \multicolumn{5}{c}{ JUMLAH } \\
\hline
\end{tabular}

Kategori tinggi mencakup skor rerata sampai dengan skor rerata ditambah $1 \mathrm{SB}$ yaitu 32,33 sampai dengan 35,43. Skor kategori tinggi dicapai 40 orang responden atau $36,36 \%$ dari seluruh responden. Kategori rendah mencakup skor rerata dikurangi $1 \mathrm{SB}$ sampai dengan rerata yaitu yang besarnya 29,23 sampai dengan 32,33. Skor kategori rendah dicapai oleh 34 orang responden atau $30,91 \%$ dari seluruh responden. Kategori sangat rendah mencakup skor minimal sampai dengan rerata dikurangi $1 \mathrm{SB}$ yang besarnya 25 sampai dengan 29,23. Skor kategori sangat rendah dicapai oleh 21 orang responden atau $19,09 \%$ dari seluruh responden.

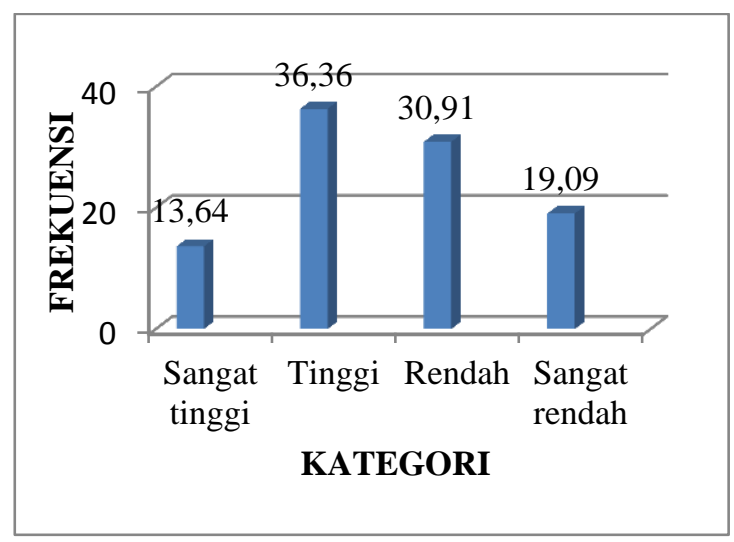

Gambar 2. Distribusi Pengalaman Pendidikan Kewirausahaan di Keluarga

\section{Pengalaman Pendidikan Kewirausahaan di Masyarakat}

Statistik deskriptif untuk variabel pengalaman pendidikan kewirausahaan di lingkungan masyarakat menunjukkan perolehan mean $(\mathrm{M})$ sebesar 9,16, median $(\mathrm{Me})$ sebesar 9, Mode (Mo) sebesar 9, dan simpangan baku (SB) sebesar 1,46. Kategori sangat tinggi mencakup skor rerata tambahan dengan $1 \mathrm{SB}$ sampai dengan skor maksimal yaitu 10,62 sampai dengan 14. Skor kategori sangat tinggi dicapai oleh 22 orang responden atau 14,38\% dari seluruh responden.

Tabel 4. Distribusi Pengalaman Pendidikan Kewirausahaan di Masyarakat

\begin{tabular}{ccccc}
\hline No & Kategori & Interval & Frekuensi & $\%$ \\
\hline 1 & Sangat & $\mathrm{X} \geq 10,62$ & 19 & 17,27 \\
& Tinggi & & & \\
2 & Tinggi & $10,62>\mathrm{X} \geq 9,16$ & 23 & 20,91 \\
3 & Rendah & $9,16>\mathrm{X} \geq 7,70$ & 55 & 50 \\
4 & Sangat & $\mathrm{X}<7,70$ & 13 & 11,82 \\
& Rendah & & \\
\hline \multicolumn{5}{c}{ JUMLAH }
\end{tabular}


Kategori tinggi mencakup skor rerata sampai dengan skor rerata ditambah 1SB yaitu 9,16 sampai dengan 10,62. Skor kategori tinggi dicapai 23 orang responden atau 20,91\% dari seluruh responden. Kategori rendah mencakup skor rerata dikurangi 1SB sampai dengan rerata yaitu yang besarnya 7,70 sampai dengan 9,16. Skor kategori rendah dicapai oleh 55 orang responden atau $50 \%$ dari seluruh responden. Kategori sangat rendah mencakup skor minimal sampai dengan rerata dikurangi $1 \mathrm{SB}$ yang besarnya 5 sampai dengan 7,70. Skor kategori sangat rendah dicapai oleh 13 orang responden atau 11,82\% dari seluruh responden.

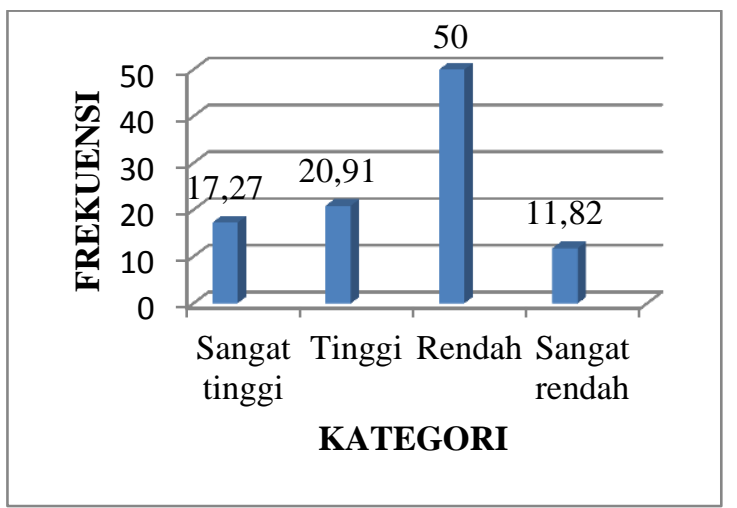

Gambar 3. Distribusi Pengalaman Pendidikan Kewirausahaan di Masyarakat

\section{Keterampilan Kejuruan}

Statistik deskriptif untuk variabel keterampilan kejuruan menunjukkan perolehan mean $(\mathrm{M})$ sebesar 71,32, median (Me) sebesar 71,50, Mode (Mo) sebesar 71, dan simpangan baku (SB) sebesar 5,88. Kategori sangat tinggi mencakup skor rerata tambahan dengan 1SB sampai dengan skor maksimal yaitu 77,20 sampai dengan 85 . Skor kategori sangat tinggi dicapai oleh 14 orang responden atau $12,73 \%$ dari seluruh responden.

Tabel 5. Distribusi Keterampilan Kejuruan Siswa SMK Tata Busana

\begin{tabular}{ccccc}
\hline No & Kategori & Interval & Frekuensi & $\%$ \\
\hline 1 & Sangat & $X \geq 77,20$ & 14 & 12,73 \\
& Tinggi & & & \\
2 & Tinggi & $77,20>X \geq 71,32$ & 41 & 37,27 \\
3 & Rendah & $71,32>X \geq 65,44$ & 36 & 32,73 \\
4 & Sangat & $X<65,44$ & 19 & 17,27 \\
& Rendah & & 110 & 100 \\
\hline \multicolumn{5}{c}{ Jumlah }
\end{tabular}

Kategori tinggi mencakup skor rerata sampai dengan skor rerata ditambah 1SB yaitu 71,32 sampai dengan 77,20. Skor kategori tinggi dicapai 41 orang responden atau $37,27 \%$ dari seluruh responden. Kategori rendah mencakup skor rerata dikurangi $1 \mathrm{SB}$ sampai dengan rerata yaitu yang besarnya 65,44 sampai dengan 71,32. Skor kategori rendah dicapai oleh 36 orang responden atau $32,73 \%$ dari seluruh responden. Kategori sangat rendah mencakup skor minimal sampai dengan rerata dikurangi $1 \mathrm{SB}$ yang besarnya 57 sampai dengan 65,44. Skor kategori sangat rendah dicapai oleh 19 orang responden atau $17,27 \%$ dari seluruh responden.

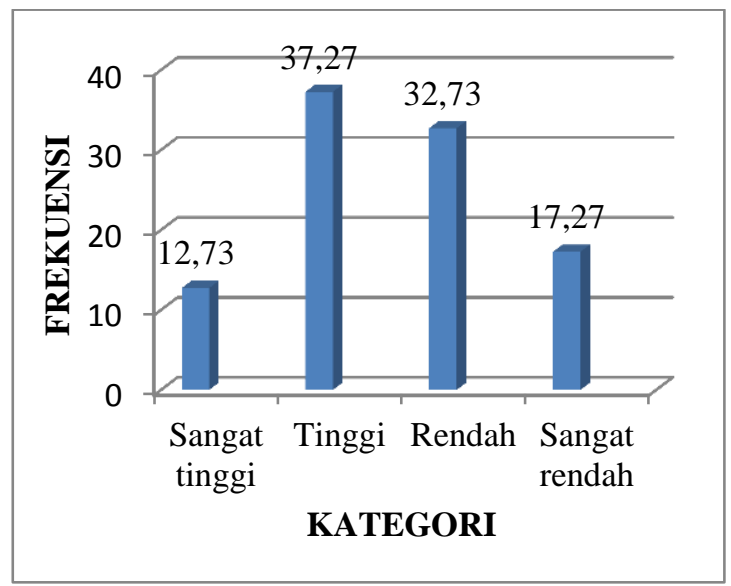

Gambar 4. Distribusi Keterampilan Kejuruan Siswa SMK Tata Busana

\section{Motivasi Berwirausaha}

Statistik deskriptif untuk variabel motivasi berwirausaha menunjukkan perolehan mean (M) sebesar 40,55, median (Me) sebesar 40,50, Mode (Mo) sebesar 40, dan simpangan baku (SB) sebesar 2,20. Kategori sangat tinggi mencakup skor rerata tambahan dengan 1SB sampai dengan skor maksimal yaitu 42,57 sampai dengan 46. Skor kategori sangat tinggi dicapai oleh 24 orang responden atau 15,69\% dari seluruh responden.

Kategori tinggi mencakup skor rerata sampai dengan skor rerata ditambah $1 \mathrm{SB}$ yaitu 40,55 sampai dengan 42,75. Skor kategori tinggi dicapai 37 orang responden atau $33,64 \%$ dari seluruh responden. Kategori rendah mencakup skor rerata dikurangi 1SB sampai dengan rerata yaitu yang besarnya 38,35 sampai dengan 40,55. Skor kategori rendah dicapai oleh 37 orang responden atau 33,64\% dari seluruh responden. Kategori sangat ren- 
dah mencakup skor minimal sampai dengan rerata dikurangi $1 \mathrm{SB}$ yang besarnya 35 sampai dengan 38,35. Skor kategori sangat rendah dicapai oleh 18 orang responden atau $16,36 \%$ dari seluruh responden.

Tabel 6. Distribusi Motivasi Berwirausaha Siswa SMK Tata Busana di Kabupaten Klaten

\begin{tabular}{ccccc}
\hline No & Kategori & Interval & Frekuensi & $\%$ \\
\hline 1 & $\begin{array}{l}\text { Sangat } \\
\text { Tinggi }\end{array}$ & $\mathrm{X} \geq 42,75$ & 18 & 16,36 \\
& $\begin{array}{c}\text { Tinggi } \\
2\end{array}$ & $\begin{array}{c}42,75>\mathrm{X} \geq \\
40,55\end{array}$ & 37 & 33,64 \\
& & & \\
3 & Rendah & $\begin{array}{c}40,55>\mathrm{X} \geq \\
38,35\end{array}$ & 37 & 33,64 \\
& & $\mathrm{X}<38,35$ & 18 & 16,36 \\
4 & $\begin{array}{l}\text { Sangat } \\
\text { Rendah }\end{array}$ & & 110 & 100 \\
\hline \multicolumn{5}{c}{ Jumlah }
\end{tabular}

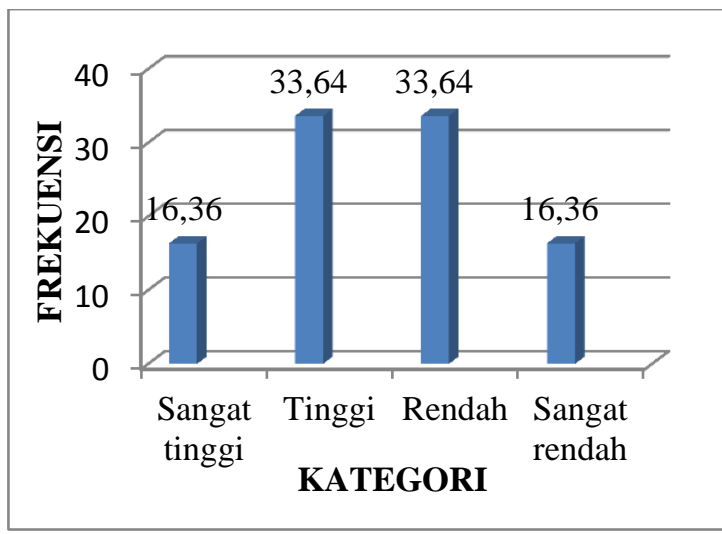

Gambar 5. Distribusi Motivasi Berwirausaha Siswa SMK Tata Busana

\section{Uji Normalitas Data}

Asumsi normalitas diuji dengan pembuatan histogram, grafik normal probability plot, dan ratio skewness. Histogram berbentuk seperti bel dengan pancaran distribusi data yang seimbang di sekitar pusat data disajikan pada Lampiran 6. Histogram tersebut menunjukkan data berdistribusi normal. dari grafik normal probability plot secara visual data (titik) menyebar di sekitar garis diagonal dan mengikuti arah garis. Grafik tersebut juga menunjukkan bahwa data berdistribusi normal. Selain itu, perhitungan ratio Skewness memperkuat keputusan bahwa data memang berdistribusi normal karena nilai ratio berada para rentang -2 sampai dengan 2. Perhitungan ratio Skewness dan Kurtosis disajikan pada Tabel 7 dan tabel 8.

Tabel 7. Perhitungan Ratio Skewness

\begin{tabular}{cccc}
\hline Variabel & Skewness & $\begin{array}{c}\text { Std. Error } \\
\text { Skewness }\end{array}$ & $\begin{array}{c}\text { Ratio } \\
\text { Skewness }\end{array}$ \\
\hline X1 & $-0,060$ & 0,23 & 0,26 \\
X2 & $-0,053$ & 0,23 & 0,23 \\
X3 & $-0,072$ & 0,23 & 0,31 \\
X4 & 0,051 & 0,23 & 0,22 \\
Y & $-0,167$ & 0,23 & 0,73 \\
\hline
\end{tabular}

Tabel 8. Perhitungan Ratio Kurtosis

\begin{tabular}{cccc}
\hline Variabel & Kurtosis & $\begin{array}{c}\text { Std. Error } \\
\text { Kurtosis }\end{array}$ & $\begin{array}{c}\text { Ratio } \\
\text { Kurtosis }\end{array}$ \\
\hline X1 & $-0,097$ & 0,457 & 0,21 \\
X2 & $-0,143$ & 0,457 & 0,31 \\
X3 & 0,222 & 0,457 & 0,48 \\
X4 & $-0,036$ & 0,457 & 0,07 \\
Y & 0,132 & 0,457 & 0,29 \\
\hline
\end{tabular}

Pada tabel 7 dan 8, semua ratio skewness dan kurtosis pada setiap variabel bernilai lebih besar dari -2 dan lebih kecil dari 2 . Dengan demikian dapat dikatakan bahwa data dari masing-masing variabel berdistribusi normal.

\section{Uji Homoskedastisitas Data}

Uji homoskedastisitas pada penelitian ini dilakukan melalui plot nilai residual model regresi. Pada Lampiran 6 sebaran plot secara visual tidak membentuk pola tertentu yang teratur (bergelombang dan melebar), sehingga dapat disimpulkan tidak terjadi heterokedastisitas. selain itu melalui Rangkuman Statistik Uji Levene Test pada Tabel 9 menunjukkan bahwa asumsi homoskedastisitas terpenuhi.

Tabel 9. Rangkuman Statistik Uji Levene Test

\begin{tabular}{ccccc}
\hline Variabel & Levene Statistic & df1 & df2 & Sig. \\
\hline X1 & 0,809 & 9 & 98 & 0,609 \\
X2 & 1,360 & 9 & 98 & 0,217 \\
X3 & 0,488 & 9 & 98 & 0,880 \\
X4 & 1,368 & 9 & 98 & 0,213 \\
\hline
\end{tabular}


Kriteria homoskedastisitas terpenuhi apabila nilai probabilitas $>0,05$. Pada Tabel 14 nilai probabilitas X1 $(0,609), \mathrm{X} 2(0,217)$, X3 $(0,880)$, dan X4 $(0,213)$ menunjukkan bahwa nilai probabilitas $>0,05$. Hal ini memperkuat kepuusan bahwa tidak terjadi heteroskedastisitas atau asumsi homoskedastisitas terpenuhi, yaitu bahwa semua kelompok populasi memiliki varian yang sama.

\section{Uji Multikolinieritas Data}

Multikolinieritas yaitu antar-variabel bebas (independen) tidak saling berkorelasi secara kuat. Untuk mengetahui hubungan tersebut, dapat dilakukan dengan cara melihat koefisien korelasi antar masing-masing variabel bebas terhadap variabel terikat $\left(\mathrm{r}_{\mathrm{x} \text {-y }}\right)$, kemudian dibandingkan dengan nilai $\mathrm{R}$ Square. Jika nilai $\mathrm{R}$ square kurang dari nilai $\mathrm{r}_{\mathrm{x}-\mathrm{y}}$, maka uji multikolinieritas terpenuhi. Hasil rekapitulasi perbandingan $r_{x-y}$ dan $R$ square dicantumkan pada tabel di bawah ini:

Tabel 10. Perbandingan Koefisien $r_{x-y}$ dan R Square

\begin{tabular}{ccc}
\hline Variabel & Koefisien $r_{x-y}$ & R Square \\
\hline$r_{x 1-y}$ & 0,286 & 0,273 \\
$r_{x 2-y}$ & 0,411 & 0,418 \\
$r_{x 3-y}$ & 0,170 & 0,148 \\
$r_{x 4-y}$ & 0,481 & 0,479 \\
\hline
\end{tabular}

Berdasarkan data pada tabel 10 di atas, diketahui bahwa nilai $\mathrm{R}$ square lebih kecil daripada Koefisien $r_{x-y}$, maka asumsi multikolinieritas terpenuhi. Dengan demikian berarti antar-variabel bebas (independent) tidak saling berkorelasi secara kuat, sehingga data sampel dapat digunakan untuk pengujian hipotesis dengan teknik analisis regresi ganda.

\section{Uji Linearitas Data}

Uji linieritas dilakukan dengan mencari persamaan garis regresi variabel bebas $\mathrm{X}$ terhadap variabel terikat Y. Hal tersebut dapat dilakukan dengan membandingkan signifikansi yang ditetapkan dengan signifikansi yang diperoleh dari analisis regresi tiap variabel $\mathrm{X}$ terhadap Y (Sig.). Asumsi linear jika nilai signifikansi regresi linearnya kurang dari 0,05 . Hasil uji linearitas disajikan pada Tabel 11.
Tabel 11. Uji Linearitas Data

\begin{tabular}{cc}
\hline Variabel X Terhadap Y & Signifikansi \\
\hline X1 & 0,004 \\
X2 & 0,000 \\
X3 & 0,124 \\
X4 & 0,000 \\
\hline
\end{tabular}

Asumsi linear jika nilai signifikansi regresi linearnya kurang dari 0,05 . Berdasarkan data pada tabel 16, diketahui bahwa nilai signifikansi X1, X2, dan X4 bernilai kurang dari 0,05 , sehingga memenuhi uji lenearitas. Sedangkan signifikansi X3 lebih dari 0,05, artinya tidak memenuhi uji lenearitas. Namun, tetap dapat dilakukan uji regresi linear karena nilainya masih tergolong kecil.

\section{Analisis Data}

\section{Uji Hipotesis Pertama}

Hipotesis pertama yaitu terdapat pengaruh positif pengalaman pendidikan kewirausahaan di sekolah terhadap motivasi berwirausaha siswa SMK Tata Busana di Kabupaten Klaten. Hipotesis ini diuji menggunakan teknik analisis regresi, untuk melihat pengaruh pengalaman pendidikan kewirausahaan di lingkungan keluarga terhadap motivasi berwirausaha. Perhitungan analisis regresi juga menggunakan software SPSS 16.0. Hasil perhitungan analisis regresi variabel pengalaman kewirausahaan di sekolah (X1) terhadap motivasi berwirausaha (Y) disajikan pada Tabel 12.

Tabel 12. Persentase Pengaruh Variabel X1 terhadap Y

\begin{tabular}{lcccc}
\hline \multicolumn{1}{c}{ Model } & $\mathrm{R}$ & $\begin{array}{c}\mathrm{R} \\
\text { Square }\end{array}$ & $\begin{array}{c}\text { Adjusted } \\
\text { R Square }\end{array}$ & $\begin{array}{c}\text { Std. Error } \\
\text { of the } \\
\text { Estimate }\end{array}$ \\
\hline $\begin{array}{l}\text { Pengalaman } \\
\begin{array}{l}\text { Kewira- } \\
\text { usahaan di } \\
\text { Sekolah }\end{array}\end{array}$ & 0,273 & 0,074 & 0,066 & 2,09692 \\
\hline
\end{tabular}

Dari tabel 12 di atas, diketahui koefisien korelasi $(\mathrm{R})$ adalah 0,273 . Nilai $\mathrm{R}$ tersebut berada pada rentang kategori rendah. Sedangkan nilai $R$ square adalah 0,074 . Nilai tersebut memiliki makna bahwa persentase pengaruh pengalaman pendidikan kewira- 
usahaan di lingkungan sekolah terhadap motivasi berwirausaha adalah $7,4 \%$. Sedangkan 92,6\% lain, dipengaruhi oleh faktor lain.

\section{Uji Hipotesis Kedua}

Hipotesis kedua yaitu Terdapat pengaruh positif pengalaman pendidikan kewirausahaan di lingkungan keluarga terhadap motivasi berwirausaha siswa SMK Tata Busana di Kabupaten Klaten. Hasil uji hipotesis ketiga melalui uji regresi disajikan pada Tabel 13.

Tabel 13. Persentase Pengaruh Variabel X2 terhadap Y

\begin{tabular}{ccccc}
\hline Model & $\mathrm{R}$ & $\begin{array}{c}\mathrm{R} \\
\text { Square }\end{array}$ & $\begin{array}{c}\text { Adjusted } \\
\mathrm{R} \text { Square }\end{array}$ & $\begin{array}{c}\text { Std. Error } \\
\text { of the } \\
\text { Estimate }\end{array}$ \\
\hline $\begin{array}{c}\text { Pengalaman } \\
\text { Kewira- } \\
\text { usahaan di } \\
\text { Keluarga }\end{array}$ & 0,418 & 0,175 & 0,167 & 1,97979 \\
\hline
\end{tabular}

Dari tabel 13 di atas, diketahui koefisien korelasi $(\mathrm{R})$ adalah 0,418 . Nilai $\mathrm{R}$ tersebut berada pada rentang kategori sedang. Sedangkan nilai $\mathrm{R}$ square adalah 0,175 . Nilai tersebut memiliki makna bahwa persentase pengaruh pengalaman pendidikan kewirausahaan di lingkungan keluarga terhadap motivasi berwirausaha adalah 17,5\%. Sedangkan $82,5 \%$ lain, dipengaruhi oleh faktor lain.

\section{Uji Hipotesis Ketiga}

Hipotesis ketiga adalah terdapat pengaruh positif pengalaman pendidikan kewirausahaan di lingkungan masyarakat terhadap motivasi berwirausaha siswa SMK Tata Busana di Kabupaten Klaten. Hasil perhitungan analisis regresi variabel pengalaman kewirausahaan di masyarakat (X3) terhadap motivasi berwirausaha (Y) disajikan pada Tabel 14.

Tabel 14. Persentase Pengaruh Variabel X3 terhadap Y

\begin{tabular}{ccccc}
\hline Model & $\mathrm{R}$ & $\begin{array}{c}\mathrm{R} \\
\text { Square }\end{array}$ & $\begin{array}{c}\text { Adjusted } \\
\mathrm{R} \text { Square }\end{array}$ & $\begin{array}{c}\text { Std. Error } \\
\text { of the } \\
\text { Estimate }\end{array}$ \\
\hline $\begin{array}{c}\text { Pengalaman } \\
\text { Kewira- } \\
\text { usahaan di } \\
\text { Masyarakat }\end{array}$ & 0,148 & 0,022 & 0,013 & 2,15566 \\
\hline
\end{tabular}

Dari Tabel 14, diketahui koefisien korelasi (R) adalah 0,148 . Nilai $R$ tersebut berada pada rentang kategori rendah. Sedangkan nilai $\mathrm{R}$ square adalah 0,175 . Nilai tersebut memiliki makna bahwa persentase pengaruh pengalaman pendidikan kewirausahaan di lingkungan masyarakat terhadap motivasi berwirausaha adalah $2,2 \%$. Sedangkan $97,8 \%$ lain, dipengaruhi oleh faktor lain.

\section{Uji Hipotesis Keempat}

Hipotesis keempat yaitu terdapat pengaruh keterampilan kejuruan Tata Busana terhadap motivasi berwirausaha siswa SMK Tata Busana di Kabupaten Klaten. Untuk membuktikan hipotesis tersebut, akan dilakukan analisis regresi variabel keterampilan kejuruan (X4) terhadap motivasi berwirausaha (Y). Hasil analisis regresi tersebut disajikan pada Tabel 15.

Tabel 15. Persentase Pengaruh Variabel X4 terhadap Y

\begin{tabular}{ccccc}
\hline Model & $\mathrm{R}$ & $\begin{array}{c}\mathrm{R} \\
\text { Square }\end{array}$ & $\begin{array}{c}\text { Adjusted } \\
\mathrm{R} \text { Square }\end{array}$ & $\begin{array}{c}\text { Std. Error } \\
\text { of the } \\
\text { Estimate }\end{array}$ \\
\hline $\begin{array}{l}\text { Keterampilan } \\
\text { Kejuruan }\end{array}$ & 0,481 & 0,232 & 0,225 & 1,93667 \\
\hline
\end{tabular}

Dari tabel 15, diketahui koefisien korelasi (R) adalah 0,481. Nilai $R$ tersebut berada pada rentamg kategori sedang. Sedangkan nilai $\mathrm{R}$ square adalah 0,232 . Nilai tersebut memiliki makna bahwa persentase pengaruh keterampilan kejuruan terhadap motivasi berwirausaha adalah $23,2 \%$. Sedangkan $76,8 \%$ lain, dipengaruhi oleh faktor lain.

\section{Uji Hipotesis Kelima}

Hipotesis kelima adalah terdapat pengaruh pengalaman pendidikan kewirausahaan di sekolah, keluarga, dan masyarakat serta keterampilan kejuruan secara bersama-sama terhadap motivasi berwirausaha siswa SMK Tata Busana di Kabupaten Klaten. Untuk membuktikan hipotesis tersebut, akan dilakukan analisis regresi ganda kedua variabel $\mathrm{X}$ yaitu pengalaman pendidikan kewirausahaan dan keterampilan kejuruan terhadap motivasi berwirausaha. Hasil regresi tersebut disajikan pada Tabel 16. 
Tabel 16. Regresi Ganda Variabel X1, X2, X3 dan X4 terhadap Y

$\begin{array}{cccc}\text { Model } & \mathrm{R} \quad \begin{array}{c}\text { Adjusted } \\ \text { Square }\end{array} & \begin{array}{c}\text { Std. Error Square } \\ \text { of the } \\ \text { Estimate }\end{array}\end{array}$

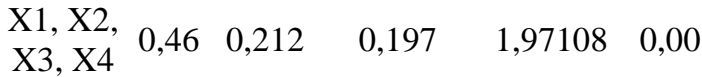

Dari tabel 16, diketahui koefisien korelasi ( $\mathrm{R})$ adalah 0,460 . nilai $\mathrm{R}$ tersebut berada pada rentamg kategori sedang. Sedangkani nilai sig. adalah 0,000 . PNilai tersebut mengindikasikan bahwa variabel pengalaman pendidikan kewirausahaan (X1) dan keterampilan kejuruan (X2) secara bersama-sama memberikan pengaruh terhadap motivasi berwirausaha siswa Tata Busana SMK di Klaten. Dengan demikian, hipotesis yang menyatakan bahwa pengalaman pendidikan kewirausahaan di sekolah, keluarga dan masyarakat serta keterampilan kejuruan secara bersama-sama berpengaruh terhadap motivasi berwirausaha siswa SMK Tata Busana di Kabupaten Klaten, telah terbukti. Sehingga, dapat disimpulkan bahwa semakin baik pengalaman pendidikan kewirausahaan dan keterampilan kejuruan, maka motivasi berwirausaha juga akan semakin baik. Untuk melihat besarnya persentase kontribusi kedua variable $\mathrm{X}$ tersebut terhadap $\mathrm{Y}$, dapat dilihat dari nilai $\mathrm{R}$ square yang ditampilkan pada tabel 17 . Nilai $R$ square adalah 0,212, yang berarti bahwa besarnya persentase pengaruh variabel $\mathrm{X}$ terhadap $\mathrm{Y}$ adalah $21,2 \%$, sedangkan $78,8 \%$ dipengaruhi oleh faktor lain.

\section{PEMBAHASAN}

\section{Motivasi Berwirausaha}

Siswa SMK pada program keahlian Tata Busana di kabupaten Klaten memiliki variasi kecendrungan motivasi berwirausaha yang beragam. Sekitar 16,36\% memiliki motivasi berwirausaha yang cenderung pada kategori sangat tinggi, dan $33,64 \%$ responden lain cenderung memiliki motivasi yang tinggi. Selain itu, sekitar 33,64\% responden memiliki motivasi rendah dan $16,36 \%$ responden memiliki motivasi pada kategori sangat rendah. Dengan demikian, persentase siswa yang memiliki motivasi tinggi untuk berwirausaha lebih besar daripada siswa yang motivasinya rendah, namun dalam selisih yang kecil. Masih banyaknya siswa yang memiliki motivasi rendah dan sangat rendah dapat disebabkan oleh berbagai faktor.

Berdasarkan temuan penelitian, dan yang menjadi variabel penelitian, faktor yang mempengaruhi motivasi berwirausaha adalah pengalaman pendidikan kewirausahaan dan keterampilan kejuruan. Baik secara parsial, maupun secara bersama-sama, kedua variabel tersebut memberikan pengaruh terhadap motivasi berwirausaha. Secara parsial, pengalaman pendidikan kewirausahaan memberikan pengaruh terhadap motivasi sebesar $20,5 \%$. Sedangkan keterampilan memberikan pengaruh sebesar 23,2\% terhadap motivasi berwirausaha. Kedua variabel tersebut memang memberikan kontribusi yang tidak besar. Namun, memiliki pengaruh yang bermakna.

Besarnya jumlah siswa program studi keahlian Tata Busana yang cenderung memiliki motivasi rendah memang tidak dapat dipastikan hanya dipengaruhi oleh rendahnya pengalaman pendidikan kewirausahaan dan keterampilan kejuruan, sebagaimana hasil penelitian. Namun, secara langsung, maupun tidak langsung, kedua faktor tersebut memiliki kontribusi terhadap rendahnya motivasi berwirausaha siswa. Artinya, jika pengalaman pendidikan kewirausahaan siswa rendah, maka motivasi berwirausaha juga rendah. Rendahnya pengalaman pendidikan kewirausahaan dapat disebabkan rendahnya pengalaman pendidikan kewirausahaan yang diperoleh di lingkungan sekolah, keluarga, dan masyarakat. Proses dan implementasi pelajaran kewirausahaan di sekolah, latar belakang pekerjaan orang tua, dan kegiatan usaha masyarakat sekitar siswa mempengaruhi motivasi berwirausaha siswa. Selain itu, keterampilan kejuruan Tata Busana juga memiliki kontribusi terhadap motivasi berwirausaha, justru lebih besar daripada kontribusi pengalaman pendidikan kewirausahaan.

Keterampilan kejuruan merupakan bekal utama yang harus dimiliki siswa untuk dikembangkan dan menghasilkan suatu produk (baik barang maupun jasa) yang memiliki nilai jual. Motivasi berwirausaha dapat muncul karena seseorang mampu menghasilkan atau memberikan nilai lebih terhadap barang maupun jasa melalui kompetensi yang dimiliki atau yang dimiliki orang lain yang dapat dikelola. 


\section{Pengalaman Pendidikan Kewirausahaan di Sekolah}

Pengalaman pendidikan kewirausahaan siswa dapat diperoleh melalui pendidikan formal, yaitu di sekolah dan non formal, yaitu di lingkungan, keluarga dan masyarakat. Dari lingkungan sekolah, sekitar $14,54 \%$ siswa cenderung pada kategori sangat tinggi dan 39,09\% pada kategori tinggi dalam hal pengalaman pendidikan kewirausahaan. Namun, persentase yang cukup besar, yaitu 33,64\% responden mendapat kategori rendah dan ditambah lagi dengan $12,73 \%$ responden pada kategori sangat rendah. Artinya, hanya sekitar separuh responden yang mengindikasikan bahwa pendidikan kewirausahaan di sekolah telah memberikan pengalaman kewirausahaan yang tinggi, sedangkan sisanya mengindikasikan mendapatkan pengalaman yang rendah.

Pengalaman pendidikan kewirausahaan di sekolah dapat diperoleh dari pelajaran kewirausahaan, saat prakerin dan kegiatan di Unit Produksi (UP). Banyaknya siswa yang mendapat pengalaman pendidikan kewirausahaan yang rendah di sekolah, dapat disebabkan oleh rendahnya pengalaman siswa pada ketiga kegiatan pembelajaran tersebut. Dari aspek pelajaran kewirausahaan, ada beberapa hal yang kemungkinan dapat menyebabkan siswa memperoleh pengalaman yang rendah, antara lain dapat disebabkan oleh rendahnya kompetensi guru dan metode penyampaian materi pelajaran yang monoton.

Kompetensi guru yang dimaksud adalah kompetensi dalam hal berwirausaha secara praktis (memiliki usaha yang telah dijalankan sendiri oleh guru). Sering ditemui fakta bahwa guru yang mengajar Kewirausaan di sekolah tidak memiliki pengalaman berwirausaha. Pengalaman berwirausaha guru akan berpengaruh terhadap materi dan metode penyampaiannya. Tanpa ada pengalaman berwirausaha, guru akan sulit memberikan materi-materi yang sifatnya praktis dan akan cenderung teoritis. Hal tersebut akan berdampak pada pandangan negatif siswa terhadap pelajaran kewirausahaan, dampak selanjutnya adalah siswa merasa jenuh. Hal tesebut akan berakibat pada rendahnya minat siswa untuk mengikuti pelajaran kewirausahaan. Sehingga, pengalaman kewirausahaan yang diperoleh siswa menjadi rendah.
Saat prakerin, siswa berpotensi mendapat pengalaman kewirausahaan, yaitu dari kegiatan prakerin di industri. Namun, isu permasalahan yang berkembang mengenai prakerin adalah rendahnya managemen prakerin, yang mengakibatkan siswa melakukan pekerjaan prakerin yang tidak sesuai dengan kompetensi keahlian, atau melakukan pekerjaan yang bukan di bagian produksi (barang/ jasa). Sehingga, pengalaman berwirausaha, yaitu memproduksi barang/jasa sangat kurang. Kalaupun mendapat pekerjaan yang sesuai, terkadang siswa selalu sibuk dan disibukkan dengan melakukan pekerjaan prakerin yang diberikan pembimbing prakerin, yaitu selalu diberikan pekerjaan yang sifatnya membantu pekerjaan pembimbing prakerin. Sehingga, pengalaman dan tanggung jawab terhadap suatu pekerjaan penting, adalah kurang. Akibatnya, pengalaman pendidikan kewirausahaan juga kurang.

Selain dari pelajaran kewirausahaan di sekolah dan prakerin di industri, pengalaman pendidikan kewirausahaan dapat diperoleh melalui Unit Produksi (UP). Unit Produksi di SMK merupakan suatu wadah yang efektif untuk menumbuuhkan sikap dan motivasi berwirausaha siswa. Melalui Unit Produksi, siswa dapat mempraktikkan bagaimana upaya untuk mengembangkan dan meningkatkan hasil kompetensi siswa menjadi sebuah peluang usaha, dengan menghasilkan suatu produk (baik barang maupun jasa). Jika suatu UP di SMK dapat berjalan dengan baik dan siswa dapat terlibat didalamnya, maka motivasi berwirausaha siswa tersebut akan tinggi. Kondisi bahwa masih banyak siswa yang memiliki motivasi berwirausaha yang rendah, juga dapat disebabkan karena rendahnya pengalaman kewirausahaan yang diperoleh siswa di UP. Hal itu dapat disebabkan antara lain karena rendahnya manajeman UP dan peran serta siswa di dalamnya. Banyaknya sekolah (SMK) yang sulit mengembangkan UP mengakibatkan kegiatan di UP sering tidak berjalan lancar atau cenderung vakum. Lama-kelamaan, hal tersebut menyebabkan Unit Produksi kurang mampu memberikan pengalaman pendidikan kewirausahaan kepada siswa.

\section{Pengalaman Pendidikan Kewirausahaan di Keluarga}

Selain mendapat pengalaman pendidikan kewirausahaan di sekolah, siswa juga men- 
dapat pengalaman kewirausahaan dari keluarga di rumah. Keluarga menjadi lingkungan yang juga efektif memberikan pengalaman pendidikan kewirausahaan. Namun, hal itu akan tergantung pada latar belakang pekerjaan dan pandangan orang tua terhadap masa depan anak. Latar belakang pekerjaan orang tua yang sebagai pengusaha, memang tidak dapat dipastikan akan memberikan pengalaman kewirausahaan kepada anaknya, atau anaknya dilibatkan pada kegiatan kewirausahaan tersebut. Tetapi, secara langsung maupun tidak langsung, akan memberikan pandangan dan motivasi kepada anak untuk berwirausaha.

Hasil penelitian menunjukkan hanya sekitar $50 \%$ siswa yang mendapat kategori tinggi dan sangat tinggi (kategori tinggi ada $36,36 \%$ dan kategori sangat tinggi $13,64 \%$ ), sisanya mendapat kategori rendah dan sangat rendah. Kondisi tersebut dapat disebabkan karena pekerjaan orang tua siswa sebagian besar adalah bukan pengusaha (buruh tani dan petani). Sepertinya hal tesebut berpengaruh terhadap rendahnya pengalaman pendidikan kewirausahaan yang diperoleh dari lingkungan keluarga. Sebagaimana yang diungkapkan oleh Potter (2008: 52), bahwa budaya dan sikap berwirausaha salah satunya dipengaruhi oleh keluarga (Family influences \& socialisation). Pengaruh lingkungan keluarga terhadap motivasi berwirausaha siswa sangat berperan penting terhadap pembentukan awal jiwa berwirausaha. Namun, berdasarkan hasil penelitian, diketahui bahwa latar belakang pekerjaan orang tua siswa bukan pengusaha. Sehingga, lingkungan keluarga cenderung tidak atau kurang memberikan pendidikan kewirausahaan. Akibatnya, motivasi berwirausaha juga kurang.

\section{Pengalaman Pendidikan Kewirausahaan di Masyarakat}

Lingkungan masyarakat juga dipercaya mampu memberikan pengalaman pendidikan kewirausahaan. Namun, berdasarkan hasil penelitian, hanya $38,18 \%$ responden yang mendapat kategori tinggi dan sangat tinggi (kategori tinggi ada $17,27 \%$ dan kategori sangat tinggi $20,91 \%$ ) dalam hal pengalaman pendidikan kewirausahaan di lingkungan masyarakat. Sedangkan responden lain cenderung pada kategori rendah dan sangat rendah. Hal tersebut dapat disebabkan oleh aktifitas masyarakat sekitar siswa. Aktivitas masyarakat di sekitar siswa akan mempengaruhi pandangan dan kegiatan siswa. Selain banyaknya masyarakat sebagai pelaku Usaha Mikro dan Kecil (UMK), tetapi juga banyak masyarakat yang mengandalkan sector pertanian dan perkebunan sebagai pekerjaan utama.

Sumber penghasilan masyarakat dari segi pertanian ternyata memberikan dampak terhadap pengalaman pendidikan kewirausahaan dan motivasi berwirausaha. Rendahnya motivasi berwirausaha siswa SMK Tata Busana di kabupaten Klaten, juga dapat disebabkan karena lingkungan sekitar siswa masih mengandalkan pertanian. Artinya, motivasi siswa tidak terfokus pada kewirausahaan tetapi juga dari segi pertanian. Sehingga kurang memberikan pengalaman pendidikan kewirausahaan dan motivasi berwirausaha siswa.

Rendahnya kategori skor diperoleh responden pada pengalaman pendidikan kewirausahaan di lingkungan keluarga dan masyarakat sepertinya memang berdampak pada rendahnya pengaruh pengalaman pengalaman pendidikan kewirausahaan terhadap motivasi berwirausaha, yaitu hanya sekitar $20,5 \%$, dan 79,5\% dipengaruhi oleh faktor lain. Artinya, rendahnya pengalaman pendidikan dari lingkungan keluarga dan masyarakat sekitar responden, nantinya akan mempengaruhi motivasi responden dalam mengambil keputusan berwirausaha.

\section{Keterampilan Kejuruan}

Siswa program studi keahlian Tata $\mathrm{Bu}$ sana di Kabupaten Klaten memiliki kategori keterampilan yang beragam. Sekitar 12,73\% memperoleh kategori sangat tinggi dan $37,27 \%$ mendapat kategori tinggi. Persentase yang cukup besar, yaitu 32,73\% responden, mendapat kategori rendah dan $17,27 \%$ mendapat kategori sangat rendah. Temuan penelitian tersebut mengindikasikan bahwa lebih besar jumlah siswa yang memiliki komptensi yang rendah, dibandingkan dengan yang memiliki kompetensi yang tinggi. Padahal, menurut Jamal (2009: 167) dan Potter (2008: 22), menyatakan bahwa keterampilan dan kewirausahaan memiliki hubungan, dan keterampilan dapat dijadikan pegangan untuk berwirausaha. Artinya, suatu keterampilan, jika dikembangkan dan fokus pada keterampilan tersebut, dapat dijadikan peluang berwirausaha. Namun, kondisi faktual penelitian me- 
ngindikasikan bahwa sebagian besar keterampilan kejuruan siswa Tata Busana masih rendah. Hal tersebut akan berakibat pada rendahnya motivasi berwirausaha siswa.

Hasil penelitian menunjukkan bahwa keterampilan kejuruan memberikan pengaruh positif terhadap motivasi berwirausaha. Dengan demikian, dapat disimpulkan bahwa semakin tinggi pengalaman pendidikan kewirausahaan maka motivasi berwirausaha akan semakin tinggi pula. Oleh sebab itu, kompetensi kejuruan Tata Busana siswa harus ditingkatkan. Selain berfokus pada peningkatan kompetensi, juga harus diimbangi dengan peluang-peluang usaha yang dapat dikembangkan siswa untuk suatu kompetensi yang diajarkan kepada siswa. Sehingga, ketika siswa mempelajari dan mendalami keterampilan kejuruan Tata Busana, siswa juga akan berfikir kreatif untuk melakukan wirausaha melalui keterampilan tersebut. Mengingat, keterampilan kejuruan memberikan pengaruh terhadap motivasi berwirausaha, yaitu $23,2 \%$. Meskipun persentase tersebut kecil, namun tetap berperan pada peningkatan motivasi berwirausaha siswa.

Salah satu upaya yang dapat dilakukan untuk meningkatkan motivasi berwirausaha melalui keterempilan kejuruan siswa adalah dengan cara memberikan gambaran peluang usaha yang dapat dikembangkan siswa pada setiap standar kompetensi/kompetensi dasar (SKKD) pembelajaran program produktif program studi Tata Busana. Dalam hal ini, guru yang memiliki peran penting. Artinya, bukan hanya guru pelajaran kewirausahaan yang bertanggung jawab terhadap motivasi berwirausaha, tetapi juga setiap guru disekolah, khususnya guru program produktif. Dimana guru program produktif juga harus mampu memberikan gambaran peluang usaha yang dapat dikembangkan siswa pada kompetensi yang diajarkan.

\section{SIMPULAN DAN SARAN}

\section{Simpulan}

Berdasarkan hasil analisis data dan dan uraian pembahasan, maka simpulan dari penelitian ini adalah:

1. Pengalaman pendidikan kewirausahaan di sekolah berpengaruh positif terhadap motivasi berwirausaha siswa SMK Tata Busana di Kabupaten Klaten.

2. Pengalaman pendidikan kewirausahaan di keluarga berpengaruh positif terhadap motivasi berwirausaha siswa SMK Tata Busana di Kabupaten Klaten.

3. Pengalaman pendidikan kewirausahaan di masyarakat berpengaruh positif terhadap motivasi berwirausaha siswa SMK Tata Busana di Kabupaten Klaten.

4. Keterampilan kejuruan berpengaruh positif terhadap motivasi berwirausaha siswa SMK Tata Busana di Kabupaten Klaten.

5. Pengalaman pendidikan kewirausahaan di sekolah, keluarga, dan masyarakat serta keterampilan kejuruan secara bersama-sama berpengaruh positif terhadap motivasi berwirausaha siswa Tata Busana SMK di Kabupaten Klaten.

\section{Saran}

Motivasi berwirausaha yang dimiliki siswa hendaknya dapat lebih ditingkatkan oleh semua pihak. Guru dan sekolah, dapat memberikan rangsangan kepada siswa untuk berwirausaha melalui metode-metode pembelajaran, memberi contoh konkrit seperti unit produksi atau business centre di sekolah, mendatangkan pakar wirausaha yang sukses sebagai pembicara untuk berbagi pengalaman dengan siswa. Keluarga atau orang tua, dapat merangsang motivasi anak dengan memberikan semangat dan kesempatan anak untuk berwirausaha. Pengalaman pendidikan kewirausahaan de sekolah dapat ditingkatkan melalui mata pelajaran kewirausahaan, prakerin maupun di Unit Produksi. Hendaknya siswa selalu dilibatkan dalam pengelolaan unit produksi agar siswa bisa belajar secara langsung bagaimana cara berwirausaha. Orang tua dan keluarga berperan aktif untuk memotivasi dan memberikan saran serta mengarahkan anaknya untuk berwirausaha sesuai potensi dan bidang yang diminati. Peran serta orang tua dan keluarga dalam pembentukan sikap yang diperlukan oleh seorang wirausaha.

Keterampilan kejuruan yang dimiliki siswa SMK Tata Busana di Kabupaten Klaten berpengaruh berarti terhadap motivasi berwirausaha. Dengan demikian agar motivasi siswa dalam berwirausaha di bidang busana semakin berkembang dengan baik selain mendapatkan pengalaman pendidikan kewirausahaan perlu adanya keterampilan kejuruan 
yang mumpuni. Guru produktif hendaknya selalu up to date mengenai trend busana, teknik dan alat dalam pembuatan busana, agar siswa lebih kreatif dalam mengembangkan keterampilan di bidang busana.

\section{DAFTAR PUSTAKA}

Ahmed, Ishfaq. et.al. (2010). Determinants of students' entrepreneurial career intentions: evidence from business graduates. European Journal of Social Sciences, 15, 14-22. Diambil pada tanggal 4 Januari 2012, dari http:// www.eurojournals.com/ejss_15_2_02.p $d f$.

Ario. (12 Mei 2009). Workshop pendidikan kewirausahaan di SMK . Diambil pada tanggal 14 agustus 2011, dari http:// www.ditpsmk.net/? page=news; OTI0 .

Badan Pusat Statistik. (2011). Berita resmi statistik. (Edisi 5 Mei 2011, No. 33/05/Th.XIV). Jakarta: Badan Pusat Statistik.

Bosma, Niels., van Praag, Mirjam., \& de Wit, Gerrit. (2000). Determinants of successful entrepreneurship. Diambil pada tanggal 14 Agustus 2011, dari http:// www.ondernemerschap.nl/pdfez/H200002.pdf.

Buchari Alma. (2010). Kewirausahaan: untuk mahasiswa dan umun. Bandung : Alfa Beta.

Depdiknas. (2003). Undang-Undang RI Nomor 20, Tahun 2003, Tentang Sistem Pendidikan Nasional.

Endro Yuwanto. (28 Mei 2010). Pendidikan wirausaha tak bisa instan. Diambil pada tanggal 14 agustus 2011 00:49, dari http://www.republika.co.id/berita/ pendidikan/berita/10/05/28/117497pendidikan-wirausaha-tak-bisa-instan

Hartono. (2010). SPSS 16.0 Analisis data statistika dan penelitian. Jakarta: Pustaka Pelajar.

Hisrich, Robert. D., Peters, Michael. P. \& Shepherd, D.A. (2005). Entrepreneurship ( $7^{\text {th }}$ ed). New York: McGraw-Hill Companies, Inc
Jamal Ma'mur Asmani. (2009). Sekolah life skills. Lulus siap kerja. Yogyakarta: Diva Press.

Kasmir. (2007). Kewirausahaan. Jakarta: PT. Raja Grafindo Persada.

Lambing, Peggy. A. \& Kuehl, Charles. R. (2003). Entrepreneurship (3 the ed). Upper Saddle River: Practice-Hall, Inc.

Leon, J.A.M, \& Giorgievski, M. (2007). Psychology of entrepreneurship: research and education. Madrid : Libreria UNED.

Mahfud \& Setyoko. (2008). Uji asumsi klasik statistic pengaruh kewenangan, kemitraan dan konflik terhadap efektivitas saluran distribusi minyak tanah menggunakan SPSS. Jurnal LIPI. Diambil pada tanggal 9 Mei 2012, dari http:// isdj.pdii.lipi.go.id/admin/jurnal/430846 0463.pdf

Marsono. (2010). Pengaruh pengetahuan kewirausahaan, dukungan keluarga, soft skill, dan prestasi belajar terhadap kesiapan berwirausaha mahasiswa teknik mesin universitas negeri yogyakarta. Tesis Magister, tidak diterbitkan, Universitas Negeri Yogyakarta.

Minat berwirausaha di Indonesia masih rendah. (23 Maret 2011). Jawa Pos National Network. Diambil pada tanggal 14 Agustus 2011, dari http://www.jpnn. com/read/2011/03/23/87627

Nur Hidayah. (2011). Faktor-faktor yang mempengaruhi motivasi berwirausaha siswa kelas xii smk negeri bidang keahlian bisnis dan manajemen di daerah istimewa yogyakarta. Tesis Magister, tidak diterbitkan, Universitas Negeri Yogyakarta.

Penganngguran di Klaten capai 25.877 jiwa. (05 November 2011). Solopos. Diambil pada tanggal 11 November 2011, pada sumber http://www.solopos.com/2011/klaten/pe ngangguran-di-klaten-capai-25-877jiwa-123023

Potter, J. (2008). Entrepreneurship and higher education. Paris: OECD. 
Profil Kabupaten Klaten. Diambil pada tanggal 14 agustus 2011 03:10, dari http:// www.umkm-soloraya.com/node/981

Saifuddin Azwar. (1997). Reliabilitas dan validitas. Yogyakarta : Pustaka Pelajar.

Sugiyono (2007). Metode penelitian pendidikan. Bandung: CV. Alfa Beta.

Sugiyono (2010). Metode penelitian kuantitatif, kualitatif, dan R\&D. Bandung: Alfa Beta.

Sukardi. (2010). Metode penelitian pendidikan. Kompetensi dan Praktiknya. Jakarta: Bumi Aksara.

Suryana. (2006). Kewirausahaan. Jakarta: Salemba Empat.

Thompson, J.F., (1973). Foundations of vocational education: Social and philosophical cConcept. New Jersey : Prentice - Hall, Inc.

TIM, (1994). Kamus besar bahasa Indonesia. Jakarta : Balai Pustaka.

UD. Sukmana. (2008). Studi tentang pengaruh pendidikan kewirausahaan terha- dap motivasi wiausaha mahasiswa universitas kuningan. Diambil pada tanggal 28 Juli 2011 21:34, dari http:// jurnal.pdii.lipi.go.id, admin,jurnal,4808123.pdf,280711,9.35.pdf

Wasty Soemanto. (1999). Pendidikan wiraswasta. Jakarta : Bumi Aksara.

Wardiman Djojonegoro.(1998). Pengembangan sumber daya manusia melalui sekolah menengah kejuruan (smk). Jakarta: Jayakarta Agung Offset.

Wurtzel, Nancy. (2007). Business motivation. Diambil pada tanggal 19 Agustus 2011, dari www.sideroad.com/entrepreneur/ business.motivation.html

Wiersma, W. (1995). Reaserch method in education: An Introduction. Ally and Bacon: University of Toledo.

Yuswati. (2007). Kesiapan wirausaha siswa jurusan tata kecantikan di DIY. Tesis Magister, tikak diterbitkan, Universitas Negeri Yogyakarta.

Yuyus Suryana., Kartib Bayu. (2010). Kewirausahaan. Jakarta: Kencana 